Technological University Dublin

DÜBLIN

ARROW@TU Dublin

\title{
Durability of Switching Behaviour After Outdoor Exposure for a Suspended Particle Device Switchable Glazing
}

Aritra Ghosh

University of Exeter

Brian Norton

Technological University Dublin, brian.norton@tudublin.ie

Follow this and additional works at: https://arrow.tudublin.ie/dubenart

Part of the Engineering Commons

\section{Recommended Citation}

Ghosh, A. \& Norton, B. (2017). Durability of switching behaviour after outdoor exposure for a suspended particle device switchable glazing. Solar Energy Materials and Solar Cells, vol. 163, pg.178-184. doi:

10.1016/j.solmat.2017.01.036

This Article is brought to you for free and open access by the Dublin Energy Lab at ARROW@TU Dublin. It has been accepted for inclusion in Articles by an authorized administrator of ARROW@TU Dublin. For more information, please contact arrow.admin@tudublin.ie, aisling.coyne@tudublin.ie,gerard.connolly@tudublin.ie.

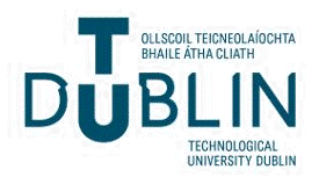




\section{Durability of switching behaviour after outdoor exposure for a suspended particle device switchable glazing}

\section{Aritra Ghosh}

aritra.ghosh@mydit.ie

aritraghosh_9@yahoo.co.in

Brian Norton

Dublin Energy Lab, Dublin Institute of TechnologyTechnology, DublinDublin, Ireland

*Corresponding author

\section{Abstract}

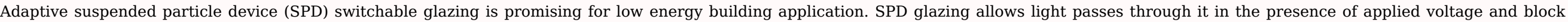

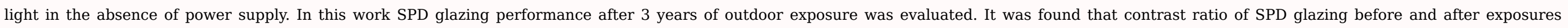

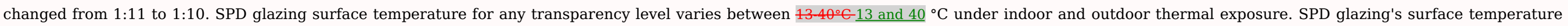

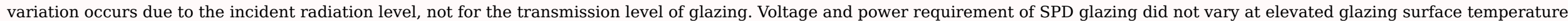

Keywords: adaptiveAdaptive glazing; glazingGlazing; SPD; temperatureTemperature; durabilityDurability; voltageVoltage

\section{Introduction}

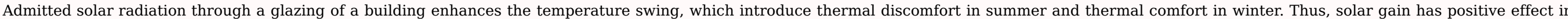

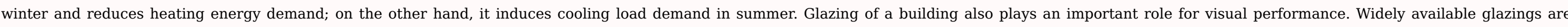

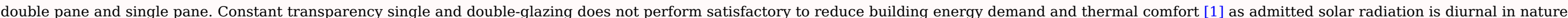
Due to sun position variation throughout the year, a vertical plane glazing often experiences variable transmittance of solar spectrum.

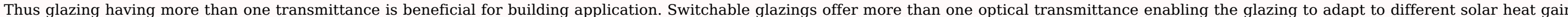
conditions [2-9].

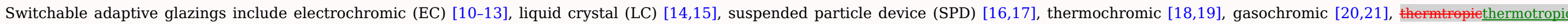

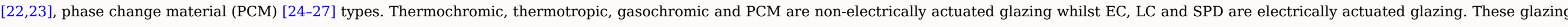

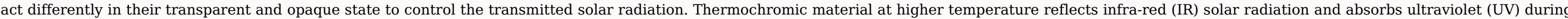

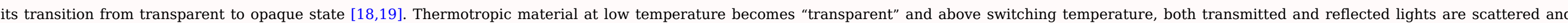

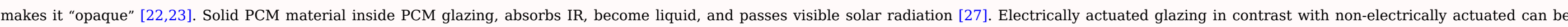
controlled based on occupant criteria.

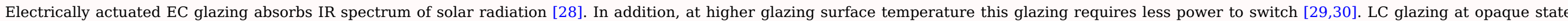
scatters the light, become haze, and provides no control of NIR [31]. SPD glazing can control only the visible solar spectrum and transmit IR spectrum [32].

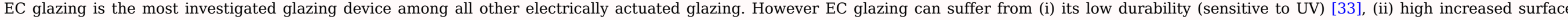

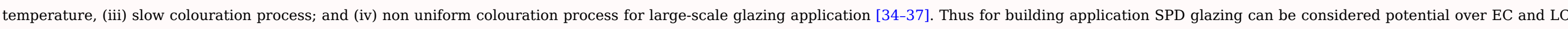
glazing. 


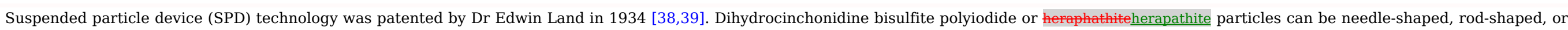

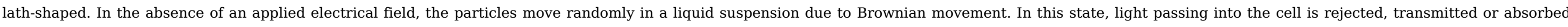

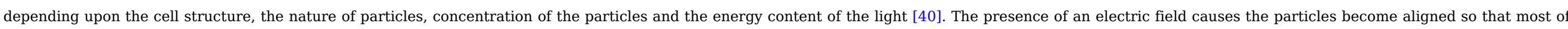

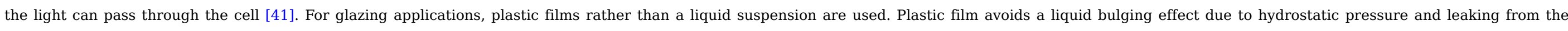

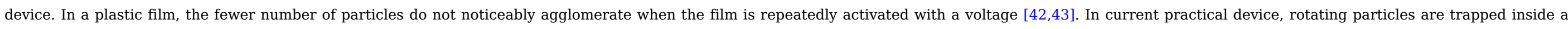
dual layer of plastic film as shown in Fig. 1. Presence of conducting layer makes it to behave like parallel plate capacitor.

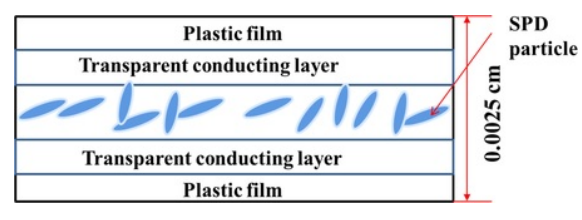

Fig. 1 Cross section of a SPD film manufactured by Research Frontiers.

\section{alt-text: Fig. 1}

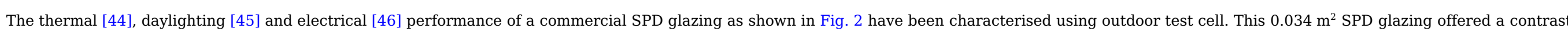

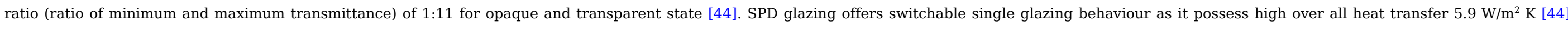

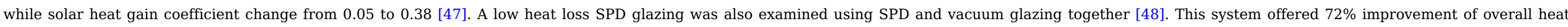

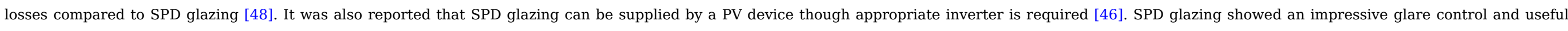
daylight illuminance control [45]. All these results make SPD glazing a viable device for use in commercial or residential building.
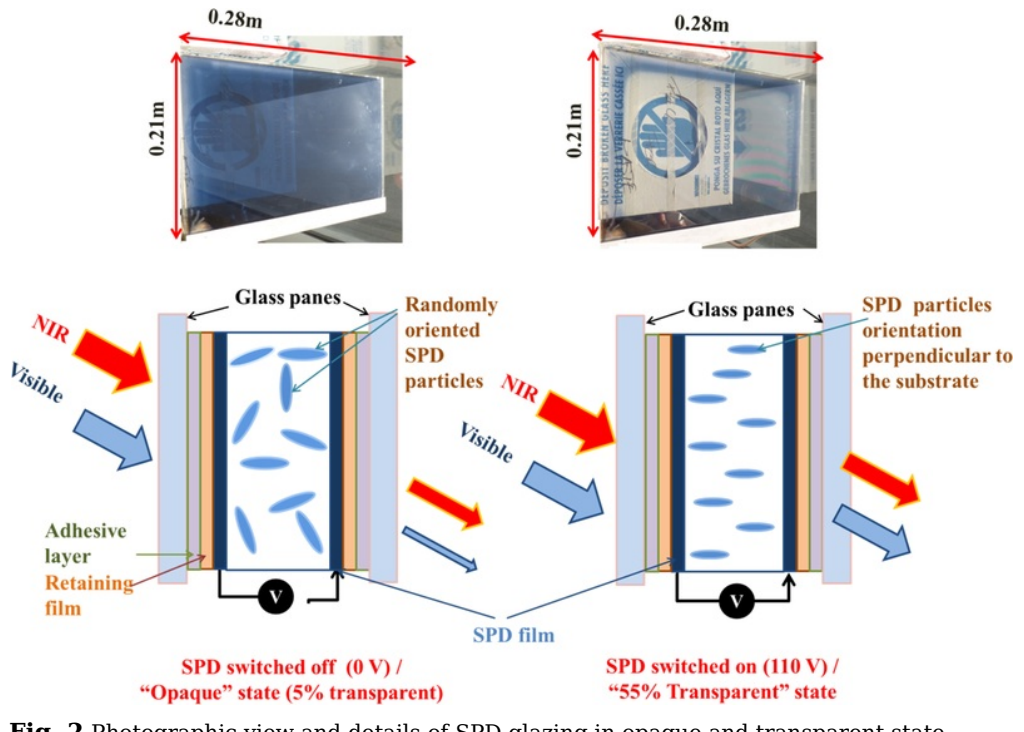

Fig. 2 Photographic view and details of SPD glazing in opaque and transparent state.

alt-text: Fig. 2

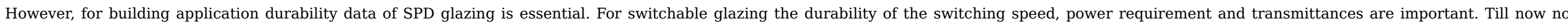
experiment has been reported about the long term switching durability of SPD glazing. 
(1) SPD glazing performance after long term outdoor exposure over 3 years;

(2) For switching SPD glazing voltage and power requirement at elevated temperature.

\section{Methodology and experiment}

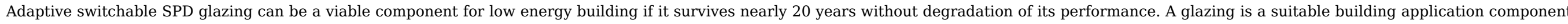

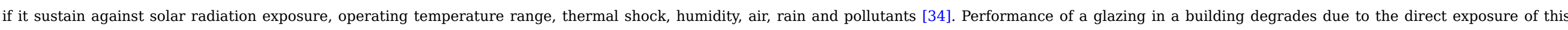
material under solar radiation specially the UV portion of spectrum has negative impact on glazing longevity. Solar energy distribution for various wavelengths is shown in Fig. 3.

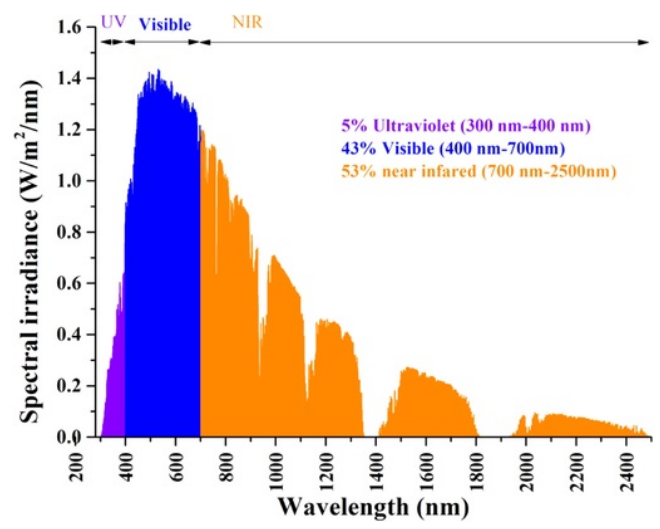

Fig. 3 Solar energy distribution

\section{alt-text: Fig. 3}

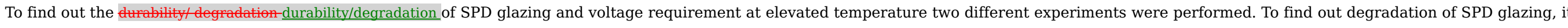

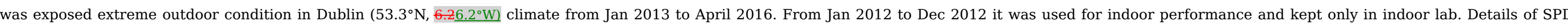

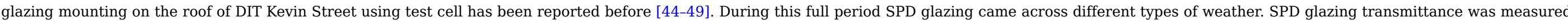
before and after outdoor exposures.

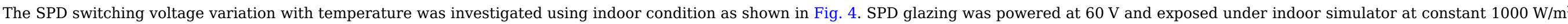

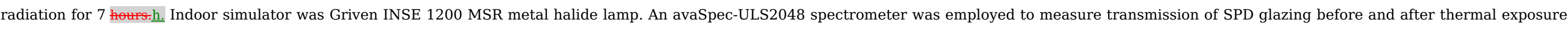

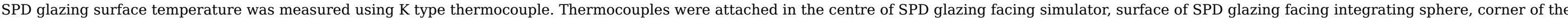
SPD glazing facing simulator and ambient room temperature. For understanding SPD glazing before outdoor exposure can be expressed as SPDb and after exposure, it is SPDa. 


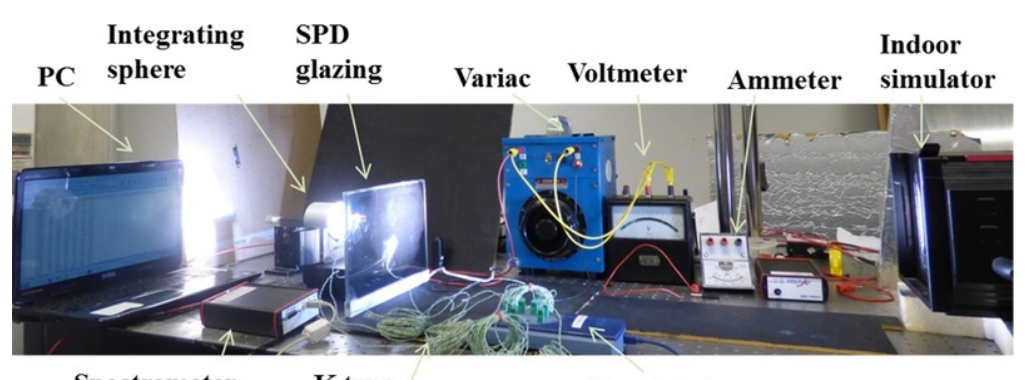

Spectrometer
K type
Pico data logger
thermocouple

Fig. 4 Indoor experiment arrangement to determine SPD glazing voltage-transmission dependency at elevated temperature.

\section{alt-text: Fig. 4}

\section{Results and discussions}

\subsection{Outdoor exposure of SPD}

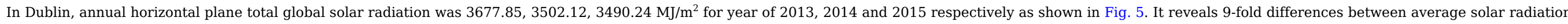

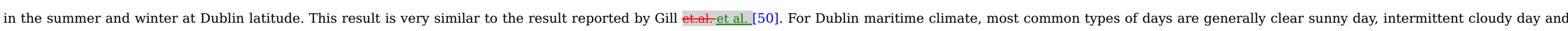

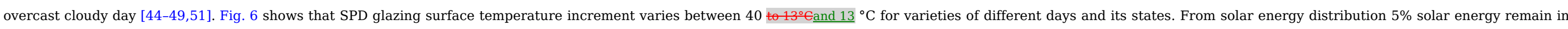
UV spectrum $(300 \underline{(300-400} \mathrm{nm})$ thus $183.8,175.1$ and $174.5 \mathrm{MJ} / \mathrm{m}^{2} \mathrm{UV}$ per year were exposed on SPD glazing. For 3 years of time this SPD glazing suffered from total $533.5 \mathrm{MJ} / \mathrm{m}^{2} \mathrm{UV}$ radiation.

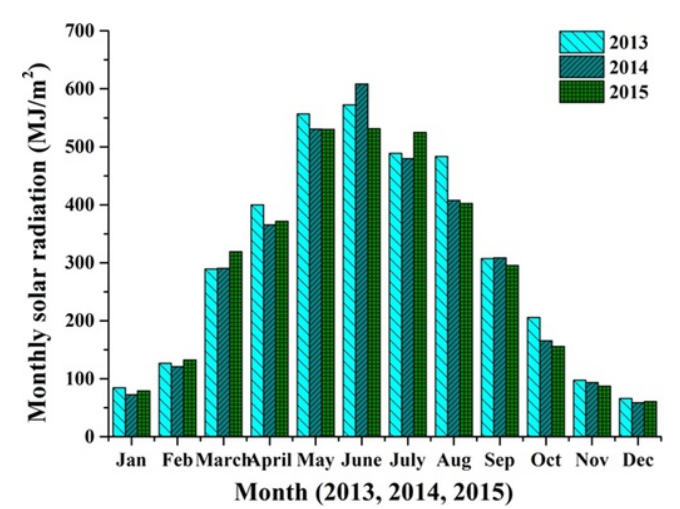

Fig. 5 Monthly average solar radiation for 2013, 2014, 2015 at Dublin, Ireland.

alt-text: Fig. 5 


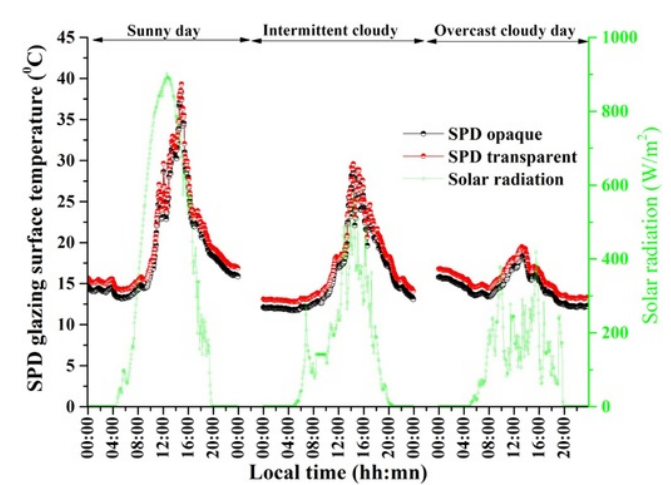

Fig. 6 SPD glazing surface temperature for typical Dublin sunny, intermittent cloudy and an overcast cloudy day for it opaque and transparent state.

alt-text: Fig. 6

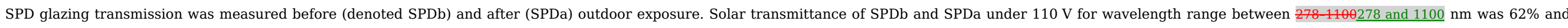

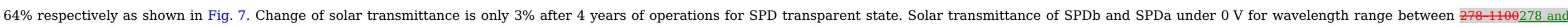

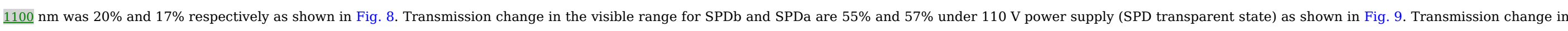

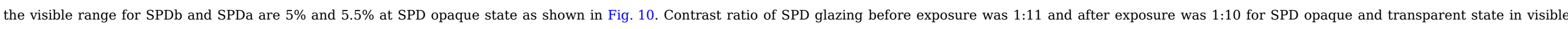

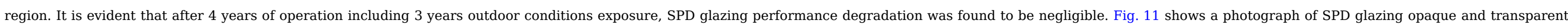
state before and after outdoor exposure. Degradation of SPD glazing transmission properties after real time UV exposure can be considered relatively less amount.

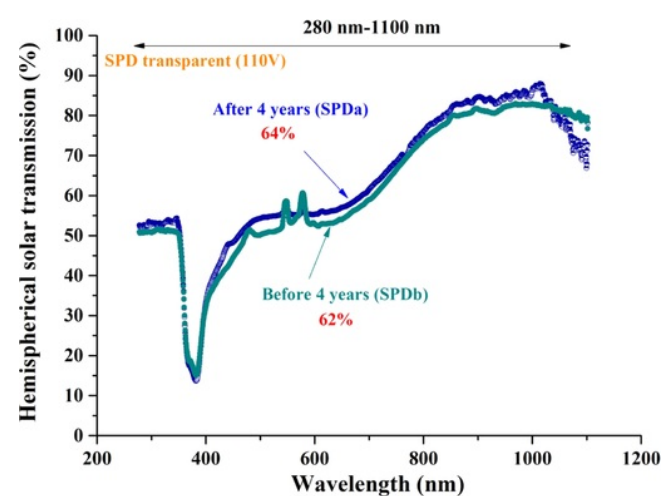

Fig. 7 Change of hemispherical solar transmittance of SPD glazing at $110 \mathrm{~V}$ before and after 4 years of operation (3 years outdoor conditions). alt-text: Fig. 7 


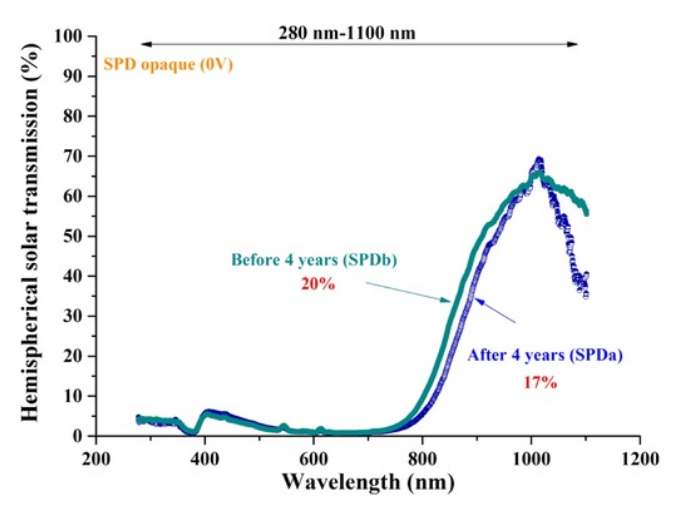

Fig. 8 Change of hemispherical solar transmittance of SPD at $0 \mathrm{~V}$ before and after 4 years of operation (3 years outdoor conditions). alt-text: Fig. 8

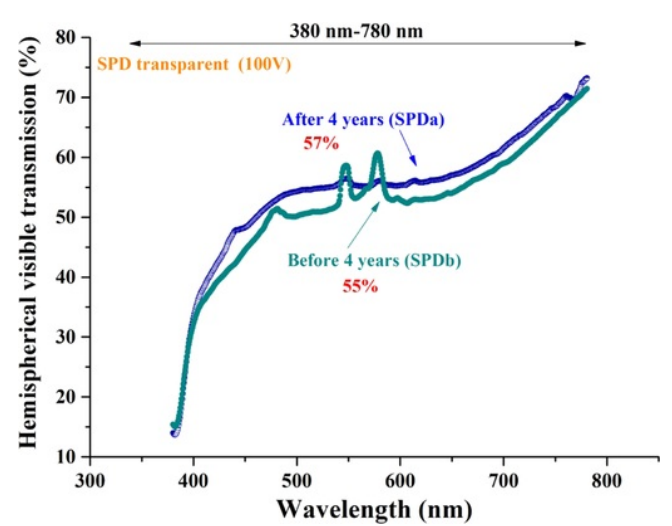

Fig. 9 Change of hemispherical visible transmittance of SPD at $110 \mathrm{~V}$ before and after 4 years of operation (3 years outdoor conditions). alt-text: Fig. 9

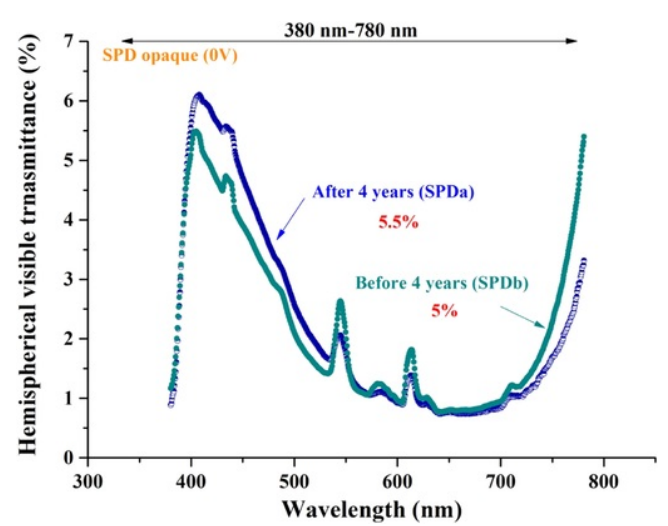

Fig. 10 Change of hemispherical visible transmittance of SPD at $0 \mathrm{~V}$ before and after 4 years of operation (3 years outdoor conditions). alt-text: Fig. 10 


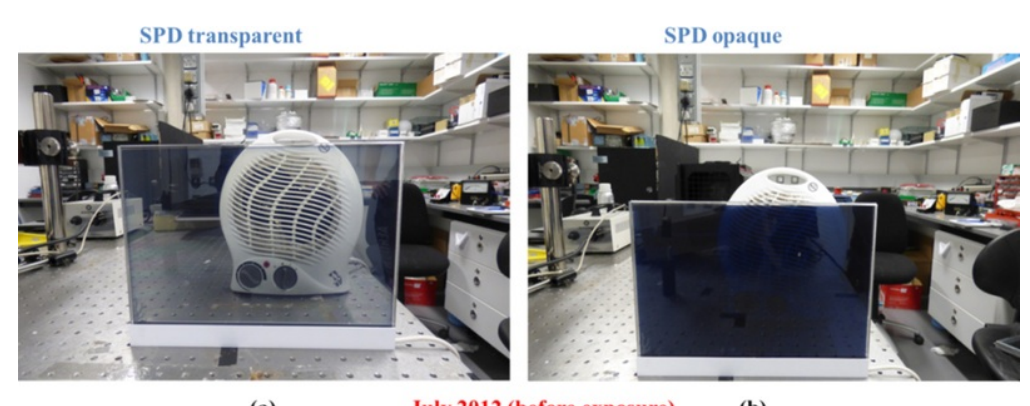
July 2012 (before exposure) (b)

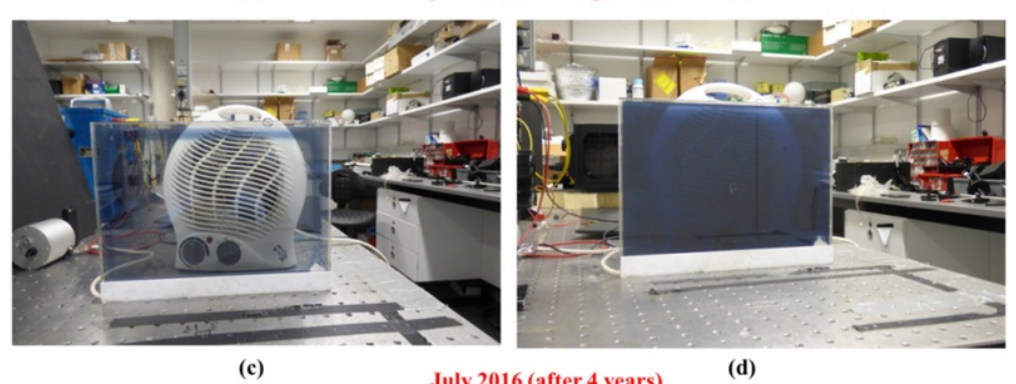

(c)

July 2016 (after 4 years)

(d)

Fig. 11 Photographs of SPD glazing (a) transparent and (b) opaque state before environmental exposure. After environmental exposure SPD glazing transparent (c) and opaque (d) states. alt-text: Fig. 11

\subsection{Variation of solar transmittance for variable voltage}

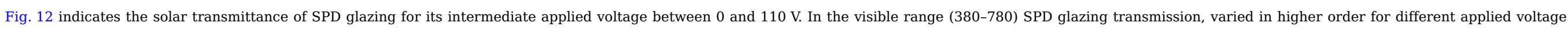
Variation was less at higher wavelength. Table 1 listed the solar transmission for different applied voltage.

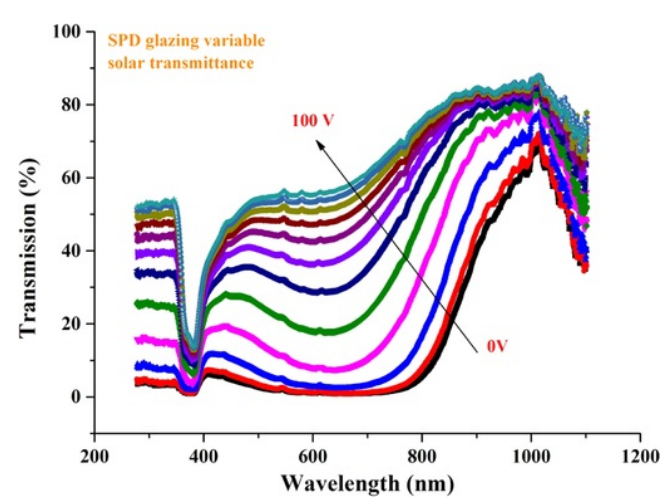

Fig. 12 Solar transmittance for SPD glazing after exposure at variable voltage. alt-text: Fig. 12

Table 1 Average solar transmittance for different applied voltage. alt-text: Table 1 


\begin{tabular}{|l|l|l|l|}
\hline 0 & 0 & 0 & 18 \\
\hline 10 & 72 & 0.00072 & 19 \\
\hline 20 & 126 & 0.00252 & 25 \\
\hline 30 & 193 & 0.00579 & 33 \\
\hline 40 & 253 & 0.01012 & 42 \\
\hline 50 & 313 & 0.01565 & 49 \\
\hline 60 & 378 & 0.02268 & 54 \\
\hline 70 & 442 & 0.03094 & 57 \\
\hline 80 & 506 & 0.04048 & 60 \\
\hline 90 & 569 & 0.05121 & 62 \\
\hline 100 & 630 & 0.063 & 63 \\
\hline 110 & 695 & 0.07645 & 64 \\
\hline
\end{tabular}

\subsection{Variation of voltage at elevated temperature}

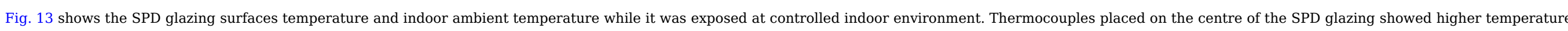

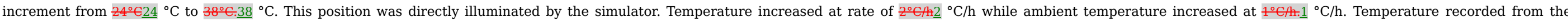

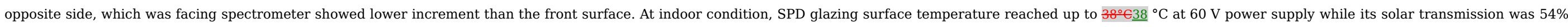

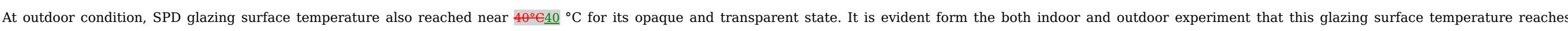

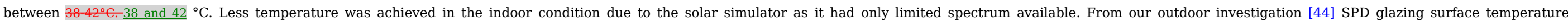
increment was found $1-2^{\circ} \mathrm{C} 1-2{ }^{\circ} \mathrm{C}$ higher than the indoor investigation. It is also confirmed that rise of SPD glazing surface temperature is independent of its transparent state.

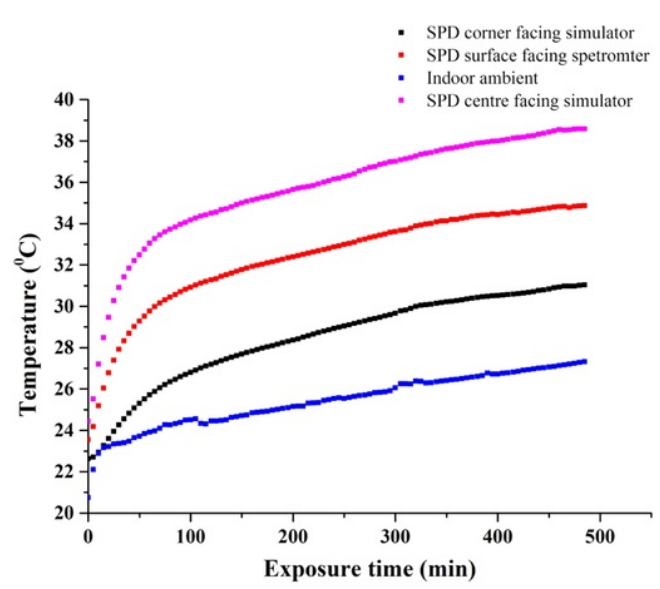

Fig. 13 SPD glazing surface temperature at controlled indoor environment. alt-text: Fig. 13 


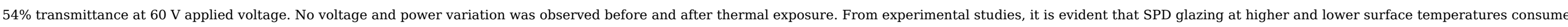
equal amounts of power to achieve a transparent state.

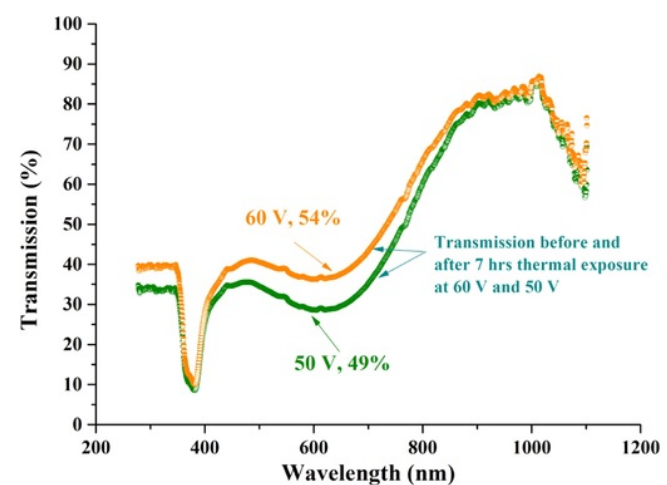

Fig. 14 SPD glazing transmission before and after 7 of thermal exposure at indoor environment at $60 \mathrm{~V}$ and $50 \mathrm{~V}$ applied voltage. alt-text: Fig. 14

\section{Conclusions}

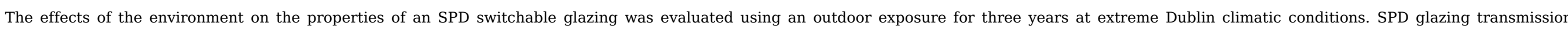

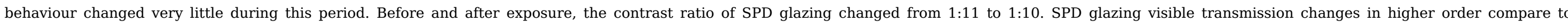

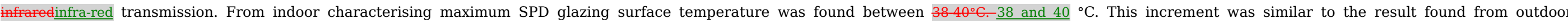

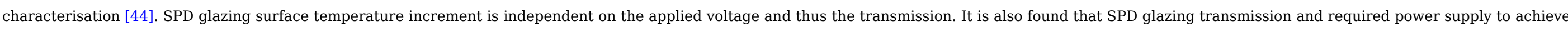
that transmission is also independent on the SPD glazing surface temperature.

\section{Acknowledgements}

The work described in this paper was supported by the Graduate Research Education Programme of the Higher Education Authority, Ireland.

\section{References}

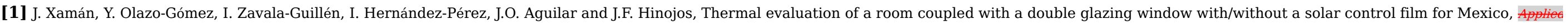
The Engling. Therm. 110, 2017, 805-820.

[2] C.M. Lampert, Optical-switching technology for glazings, Thin Solid Films 236, 1993, 6-13.

[3] C.M. Lampert, Large-area smart glass and integrated photovoltaics, Solat Sol. Energy Materials \& Solar Mater. Sol. Cells 76, 2003, 489-499.

[4] G. Gorgolis and D. Karamanis, Solar energy materials for glazing technologies, Solar Sol. Energy Materials and Solar Mater. Sol. Cells 144, 2016, 559-578.

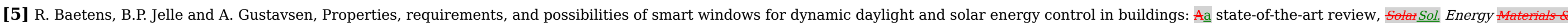
Solar Mater. Sol. Cells 94, 2010, 87-105.

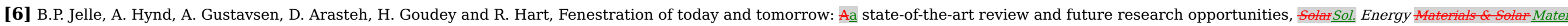
Sol. Cells 96, 2012, 1-28.

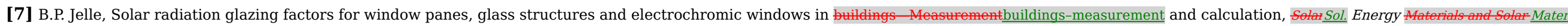


Sol. Cells 116, 2013, 291-323.

[8] A. Seeboth, J. Schneider and A. Patzak, Materials for intelligent sun protecting glazing, Solar Sol. Energy Materials and Solar Mater. Sol. Cells 60, $2000,263-277$.

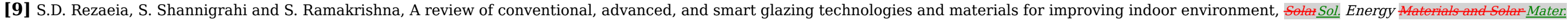
Sol. Cells 159, 2017, 26-51.

[10] C.M. Lampert, Chromogenic smart materials, MaterialsMater. Today 7, 2004, 28-35.

[11] C.G. Granqvist and V. Wittwer, Materials for solar energy conversion: Anan overview, SolarSol. Energy Materials \& Solar Mater. Sol. Cells 54, 1998 , 39-48.

[12] C.G. Granqvist, Electrochromic tungsten oxide films: Reviewreview of progress 1993 19981993-1998, SolarSol. Energy Materials \& Solar Mater. Sol. Cells 60, $2000,201-262$.

[13] C.G. Granqvist, Oxide electrochromics: Anan introduction to devices and materials, Solar Sol. Energy Materials \& Solar Mater. Sol. Cells 99, 2012 , 1-13.

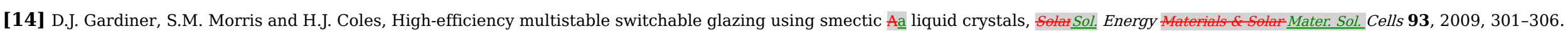

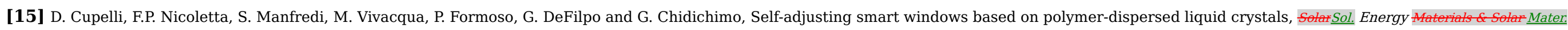
Sol. Cells 93, 2009, 2008-2012.

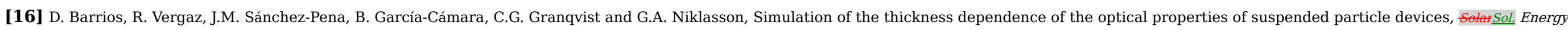
Aaterials and Solar Mater. Sol. Cells 143, 2015, 613-622.

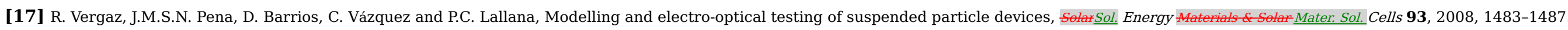

[18] M.H. Lee, Thermochromic glazing of windows with better luminous solar transmittance, Solar Sol. Energy Materials and Solar Mater. Sol. Cells 71, 2002, 537-540.

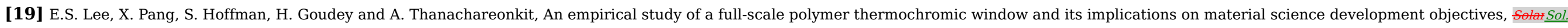
Energy Materials \& Solar Mater. Sol. Cells 116, 2013, 14-26.

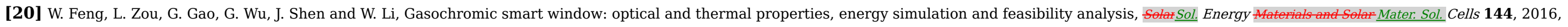
316-323.

[21] A. Georg, W. Graf, R. Neumann and V. Wittwer, Stability of gasochromic WO3 films, SolatSol. Energy Materials Solar Mater. Sol. Cells 63, 2000, 165-176.

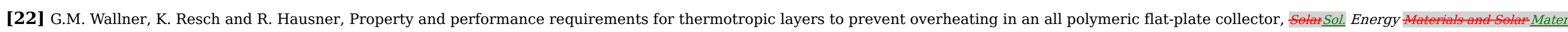
Sol. Cells 92, 2008, 614-620.

[23] H. Watanabe, Intelligent window using a hydrogel layer for energy efficiency, Solar Sol. Energy Materials \& Solar Mater. Sol. Cells 54, 1998, 203-211.

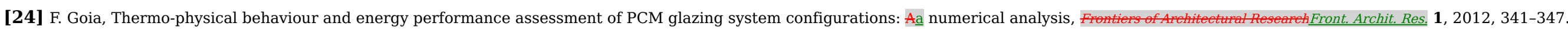

[25] F. Goia, M. Perino and V. Serra, Experimental analysis of the energy performance of a full-scale PCM glazing prototype, SolatSol. Energy 100, $2014,217-233$.

[26] F. Goia, M. Perino and V. Serra, Improving thermal comfort conditions by means of PCM glazing systems, Energy and Buildings Build. 60, 2013, 442-452.

[27] F. Goia, M. Zinzi, E. Carnielo and V. Serra, Spectral and angular solar properties of a PCM-filled double glazing unit, Energy and BuildingsBuild 87, 2015, 302-312.

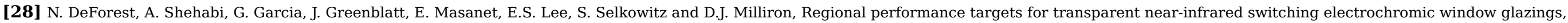
Building and Enviromentild. Environ, 61, 2013, 160-168. 
[29] J.P. Matthews, J.M. Bell and I.L. Skryabin, Effect of temperature on electrochromic device switching voltages, ElectrochimicaElectrochim. Acta 44, 1999 , 3245-3250.

[30] J.P. Matthews, J.M. Bell and I.L. Skryabin, Simulation of electrochromic switching voltages at elevated temperatures, ElectrochimieaElectrochim. Acta 46, $2001,1957-1961$.

[31] C.M. Lampert, Smart switchable glazing for solar energy and daylight control, SolarSol. Energy Materials \& Solar Mater. Sol. Cells 52, 1998, 207-221.

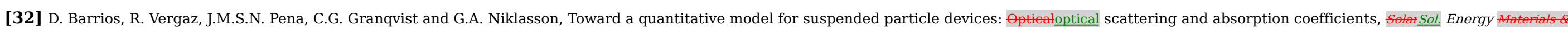
Solar Mater. Sol. Cells 111, 2013, 115-122.

[33] C.E. Tracy, J.G. Zhang, D.K. Benson, A.W. Czanderna and S.K. Deb, Accelerated durability testing of electrochromic windows, ElectroehimiedElectrochim. Acta 44, 1999, 3195-3202.

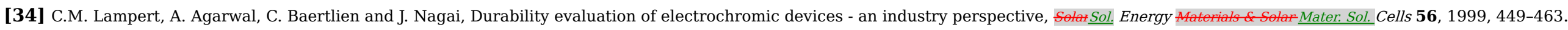

[35] C.M. Lampert, T.R. Omstead and P.C. Yu, Chemical and optical properties of electrochromic nickel oxide films, Solar Sol. Energy MaterialsMater. 14, 1986, 161-174.

[36] K.C. Ho, The influence of charge capacity ratio on the performance of a complementary electrochromic system, Solar Sol. Energy Materats and Solar Mater. Sol. Cells 56, 1999, 271.

[37] E.S. Lee and D.L. DiBartolomeo, Application issues for large-area electrochromic windows in commercial buildings, Solar Sol. Energy Materials \& Solar Mater. Sol. Cells 71, 2002, 465-491.

[38] E. H.E.H. Land, Light valveValve and methodMethod of operation,Operation, U.S. Patent No. 1,955,923 (1,955,923, 1934),

[39] A.M. Marks, ElectropticatElectro optical characteristics of dipole suspensions, Applied OptiesAppl. Opt. 8, 1969, 1397-1412.

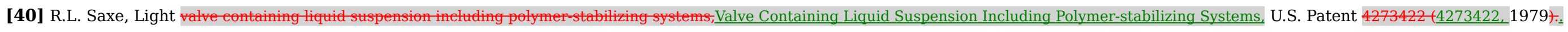

[41] R.L. Saxe, Light valve suspension eontaining fluorocarbon liquid,Valve Suspension Containing Fluorocarbon Liquid, U.S. Patent US4407565 (US4407565, 1981).

[42] S. Charapani, S.M. Slovak, R.L. Saxe, B. Fanning, , SPD filmsFilms and light valves comprising same,Light Valves Comprising Same, US Patent 6416827 (6416827, 2002).

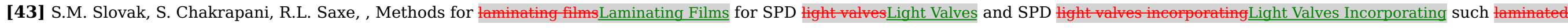
films,Laminated Films, U.S. Patent US20050227061 US20050227061, 2005).

[44] A. Ghosh, B. Norton and A. Duffy, Measured overall heat transfer coefficient of a suspended particle device switchable glazing, ApplieiAppl. Energy 159, 2015, 362-369.

[45] A. Ghosh, B. Norton and A. Duffy, Daylighting performance and glare calculation of a suspended particle device switchable glazing, Solar Sol. Energy 132, $2016,114-128$.

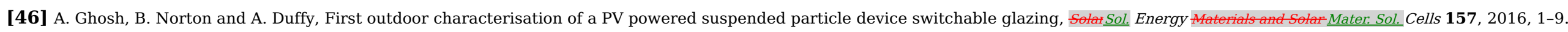

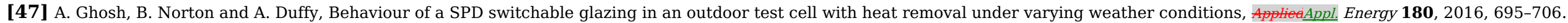

[48] A. Ghosh, B. Norton and A. Duffy, Measured thermal performance of a combined suspended particle switchable device evacuated glazing, ApplieaAppl. Energy 169, 2016, 469-480.

[49] A. Ghosh, B. Norton and A. Duffy, Measured thermal \& daylight performance of an evacuated glazing using an outdoor test cell, AppliedAppl. Energy 177, $2016,196-203$.

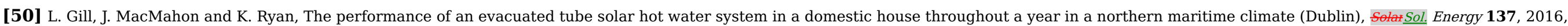
261-272.

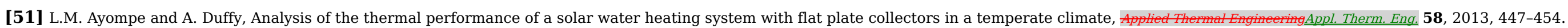

\section{Highlights}




\section{Queries and Answers}

Query:

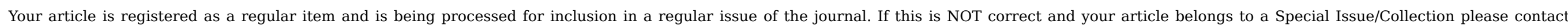
j.alwyn@elsevier.com immediately prior to returning your corrections.

Answer: Its a regular item.

Query:

Highlights should consist of 3-5 bullet points. There are "2" bullet points provided and hence edited to meet the requirement. Kindly validate the change made.

Answer: SPD glazing power requirement independent to its surface temperature variation

Query:

Please confirm that given names and surnames have been identified correctly and are presented in the desired order.

Answer: Yes 